\title{
Challenges in marketing channel selection by smallholder pineapple growers in Samarahan, Sarawak, Malaysia
}

\author{
${ }^{1}$ Nahar, A., ${ }^{2,}$ "Saili, A.R., ${ }^{3}$ Hamzah, N.M., ${ }^{1}$ Abdul Fatah, F., ${ }^{2}$ Yusop, Z. and \\ ${ }^{1}$ Kamarul Zaman, N.B. \\ ${ }^{1}$ Faculty of Plantation and Agrotechnology, Universiti Teknologi Mara (UiTM), Cawangan Melaka, \\ Kampus Jasin, 77300 Merlimau, Melaka, Malaysia \\ ${ }^{2}$ Faculty of Plantation and Agrotechnology, Universiti Teknologi Mara (UiTM), Cawangan Sarawak, Jalan \\ Meranek, 94300 Kota Samarahan, Sarawak, Malaysia \\ ${ }^{3}$ Faculty of Plantation and Agrotechnology, Universiti Teknologi MARA (UiTM), Cawangan Pahang, 26400 \\ Bandar Tun Abdul Razak Jengka, Pahang, Malaysia
}

\author{
Article history: \\ Received: 23 July 2020 \\ Received in revised form: 13 \\ October 2020 \\ Accepted: 15 December 2020 \\ Available Online: 20 \\ December 2020
}

\section{Keywords:}

Marketing channel,

Smallholder,

Pineapple,

Middlemen,

Challenges,

Marketing

DOI:

https://doi.org/10.26656/fr.2017.4(S5).020

\begin{abstract}
Pineapples are very perishable and require an immediate sale to consumers. This has triggered the local growers to market their produce and rely on the middleman. Thus, this present study was conducted to identify the challenges that affect the marketing channel selection of smallholder pineapple growers in Samarahan, Sarawak. The primary data used for this study were collected from 123 smallholder pineapple growers using simple random sampling method with a well-structured close-ended questionnaire via face-toface survey. The descriptive analysis was used to describe the socio-demographic characteristics of the pineapple growers meanwhile exploratory factor analysis (EFA) using principal component analysis approach with orthogonal rotation (varimax) was used to reduce data to a smaller set of summary variables and to identify the structure of the relationship between the variables and the respondents. The findings revealed that five main challenges have caused pineapple growers to carefully select the marketing channel in marketing their produce namely; lack of market information; inefficient transportation; price volatility; market distance; and product perishability. Inadequate marketing information about supply and demand markets, potential buyers, bargaining, and negotiation have caused concerned for the pineapple growers to take the risk in marketing their produce to various customers. Lack of transportation facility and high transportation cost has caused the pineapple growers to sell their produce at the farm gate to reduce losses during the distribution channel. Moreover, the unstable pineapple price has created a risk to the growers due to its negative effect on farm income stability. Besides, the distance between farms and marketplace has significantly affected marketable surplus of pineapple fruits thus resorts to the growers to rely on the middleman to market their produce. Conclusively, all the challenges highlighted in this study should be given adequate attention by the relevant agencies to improve and continue their effective roles in the pineapple market and to enhance farmers' livelihoods. This can be achieved by strengthening the fruit supply chain management, adopting comprehensive approaches such as policies, programs and strategies pertaining to the marketing of pineapple fruits that require a collective effort and commitment from the public and private sectors.
\end{abstract}

\section{Introduction}

Sarawak, which contributes $98 \%$ of the country's black pepper, is now poised to be the largest premium pineapple hub in the country (Ministry of Modernisation of Agriculture, Native Land and Regional Development Sarawak, 2020). As stated in a 2017 statistic by
Malaysian Pineapple Industry Board, pineapple farming in Sarawak covers about 1,342 hectares of land with a total production of 38,025 metric tons generating revenue of RM48.22 million and currently is the secondlargest pineapple producing state in Malaysia after Johor with 8,429 hectares (David, 2019). Ananas comosus is an important tropical fruit from the Bromeliaceae family. 
After bananas, the pineapple was recognized by the United Nations Conference on Trade and Development (UNCTAD) in the ranking of commercial tropical fruits for production on a worldwide basis (UNCTAD, 2016). Pineapple is a wonderful tropical fruit having exceptional juiciness and vibrant tropical flavour packed with immense health benefits. Joy (2010) stated that pineapple contains a considerable amount of calcium, potassium, fibre, and vitamin $\mathrm{C}$ and a good source of vitamin B1, vitamin B6, copper, and dietary fibre.

Currently, there are nine major pineapple varieties planted in Malaysia, namely Moris, N36, Sarawak, Moris Gajah, Gandul, Yankee, Josapine, Masapine and most recently MD2 (Thalip et al., 2015). Milie Dilard 2 or MD2 has been identified as a key crop under the National Key Economic Area (NKEA) of the Economic Transformation Program (ETP). UNCTAD (2016) stated that the local prices of fresh pineapple have tended to dip in European markets under the effect of the growing supply. Moreover, the increased supply in the Costa Rican in the early 2000s, with the MD2 variety, first caused an increase in demand which was accompanied by a steep rise in prices, peaking in 2003. But, some of the top ten fresh pineapple exporters especially the Asian countries only exports approximately $20 \%$ of its fresh produce, the remaining $80 \%$ is mainly aimed at processing such as in Thailand, the Philippines, Indonesia, and China (UNCTAD, 2016). Pineapple can be consumed fresh, or it can be processed into canned, juiced, and are found in a wide array of food packagingdessert, fruit salad, jam, yoghurt, ice cream, candy, and as a complement to meat dishes (Chaudhary et al., 2019).

According to Jaji et al. (2018), their study indicated that pineapple industry contributes significantly to the country's socio-economic development in terms of improving livelihoods of smallholder farmers through incomes generation. Sigei (2014) stated that it is important for smallholder farmers to market the agricultural produce as they provide job opportunities for the rural community. Smallholder farmers must select high-value markets, such as exporting and processingoriented marketing channels, in the pineapple supply chain to generate more income. This is possible because fruit and vegetable farms have numerous channels through which they can market their products. Arinloye et al. (2015) stated that there are four main marketing channels consists of rural, urban, export fresh pineapple markets, and processing-oriented markets. Most common among these options are direct-to-consumer sales (e.g., farmers' markets, roadside stands), direct-to-institution outlets (e.g., schools, hospitals, other institutional foodservice operations), and intermediated outlets such as wholesalers, distributors, restaurants, or grocers (Barrowclough et al., 2019). For the rural farmers, marketing channel selection is one of the key elements to the successful marketing of their products as different channels are characterized by different costs and profitability. For instance, selling to brokers or collectors at the farm gate due to the lack of access to transportation or insufficient credit often give less remunerative to the farmers. The evidence found by Fafchamps and Hill (2005) that the crop price received by farmers varies between channels for sales has implications for the welfare impact of commercialization.

Marketing channel as defined by (Stern et al., 1996) is a set of interdependent organizations involved in the process of making a product or service available for consumption or use. Makhura (2001) inspected that the marketing of smallholder farmers was constrained by poor infrastructure, distance from the market, lack of own transportation, and inadequate market information. A study in West Bengal done by Das et al. (2016) revealed that there are six major marketing channels through which pineapple fruits are transacted from producers to consumers (Table 1). Additionally, Figure 1 shows the supply chain structure in Johor, starting from the farmers until the end customers (Zakaria and Abdu Rahim, 2014). From the figure shown, there are several levels involved in fruit supply chain starting from farmers, intermediaries, and lastly the consumers. There is, however, a growing interest among supply chain stakeholders for small-scale farmers to shift their participation in traditional into intermediated channels such as marketing their products in mainstream grocery and retail venues where consumers are already shopping (Clark and Inwood, 2016). Accommodating these requests can be challenging, requiring buyers to integrate

Table 1. Marketing channel of pineapple fruit in West Bengal

\begin{tabular}{ll}
\hline Marketing channel & Channel chain \\
\hline Channel-1 & Producer $\rightarrow$ Wholesaler $\rightarrow$ Outside markets $\rightarrow$ *Consumer \\
Channel-2 & Producer $\rightarrow$ Trade agent $\rightarrow$ Wholesaler $\rightarrow$ Outside market $\rightarrow$ *Consumer \\
Channel-3 & Producer $\rightarrow$ Wholesaler $\rightarrow$ Retailer Consumer \\
Channel-4 & Producer $\rightarrow$ Trade agent $\rightarrow$ Wholesaler $\rightarrow$ Retailer $\rightarrow$ Consumer \\
Channel-5 & Producer $\rightarrow$ Wholesaler $\rightarrow$ Factory $\rightarrow$ Outside market $\rightarrow{ }^{*}$ Consumer \\
Channel-6 & Producer $\rightarrow$ Wholesaler $\rightarrow$ Middle agent $\rightarrow$ Outside market $\rightarrow$ *Consumer \\
\hline
\end{tabular}

*incomplete channel is an open channel that is extended to the markets in other states 
smaller farms into their supply chain network and develop strategies to manage the frequently more-varied quantities, quality, and production practices from these farms. Zakaria and Abdul Rahim (2014) stated that the distance of farm which is lengthy to the consumers had affected the selection of marketing channel by the smallholders.

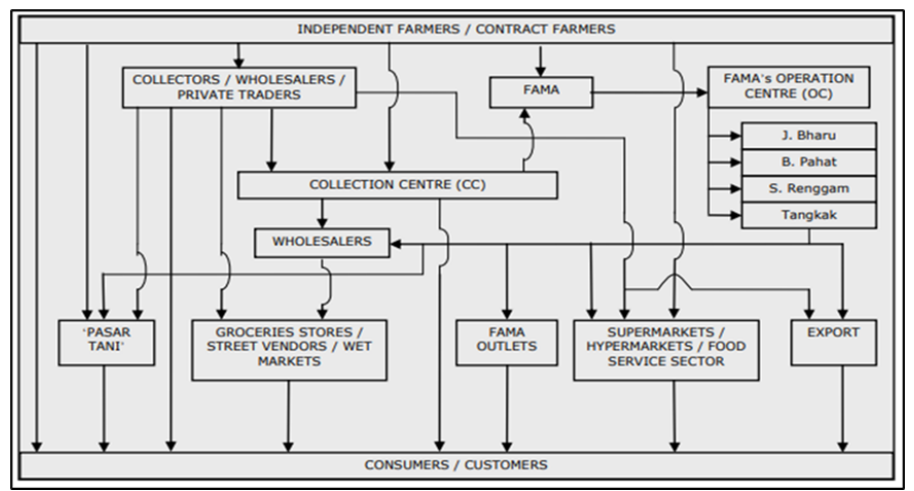

Figure 1. Fruit supply chain in Johor

The Samarahan district is one of the pineapple cultivation project areas in Sarawak. The areas were previously implemented by the Integrated Agriculture Development Area (IADA) Samarahan which were then taken over by Malaysian Pineapple Industry Board (MPIB) (Assis et al., 2014). With the effort of the government to produce fresh pineapple products especially from the MD2 variety as Sarawak has vast landmass and a large tract of peat soil, it has big potential to become the nation's main pineapple producer. Hence, using an intermediary is important to solve the ineffective marketing system such as the used of contracts to facilitate transactions between small-scale farms and wholesalers. However, the selection of marketing channels is one of the important factors for pineapple growers in Samarahan because different channels are characterized by different profitability and cost. Understanding the challenges influencing the channel selection is essentials to improve farm income and investment condition especially for small scale pineapple production. This paper was therefore aimed at identifying the challenges that affect the marketing channels selection of pineapple growers in Samarahan, Sarawak so as to be able to point out the necessity of pineapple growers to increase their production and also formulate the strategic plans and policies for the development of smallholder marketing abilities.

\section{Materials and methods}

The study was carried out in Samarahan, Sarawak, Malaysia. According to the Department of Agriculture, Sarawak is listed as the second top producing state in Malaysia after Johor for pineapple production in 2017 with the estimated volume of production of 25,664 metric tons (Nurul Hidayah and Fazleen, 2019).
Samarahan was chosen due to its characteristics of being the largest pineapple planting district with 357.95 ha or 37 per cent of the total planted areas across Sarawak in 2016 (Veno, 2018). It is a district with an area of 593.9 $\mathrm{km}$ square coordinated at $1^{\circ} 45^{\prime} 99^{\prime \prime}$ North and longitude $110^{\circ} 48^{\prime} 83^{\prime \prime}$ East. Samarahan was, therefore, chosen as the study area. The specific areas or villages in the Samarahan district selected for the study were Meranek, Niup, Naie Baru, Melayu, Sungai Mata, Empila, Mang, Tanjung Parang, Asajaya, Lubuk Punggo, and Tambey. The primary data used for this study were collected from 123 smallholder pineapple growers selected using simple random sampling method with a well-structured closeended questionnaire via face-to-face survey. The instrument used for data collection consisted of two sections of A, and B. Section A comprised of questions on demographic of pineapple growers and Section B covered the challenges faced by the smallholder pineapple growers in selecting marketing channel to market their pineapples products. To ensure the validity of the instrument it was pre-tested to detect weakness in design and a wide range of other potential problems associated with the instrument. The results from the pilot study were used to fine-tune the questionnaire for the final data collection. Furthermore, the reliability analysis was conducted using Cronbach's alpha to examine the internal consistency of items for each of the construct. The results showed Cronbach's Alpha is 0.719 that is in the range of acceptable internal consistency of $0.8>\alpha \geq$ 0.7 . This indicated that the reliability of the items measured in each of these indices are satisfactory and the internal consistencies are quite high.

\subsection{Data collection analysis}

The descriptive analysis and exploratory factor analysis (EFA) were used to analyse the data using the Statistical Package for Social Science (SPSS) software version 22. Descriptive analysis was used to describe the socio-demographic characteristics of the pineapple growers in frequencies and percentages. Exploratory factor analysis using principal component analysis approach with orthogonal rotation (varimax) was used to identify the most important variables from the large number of variables in the data set that affect the selection marketing channels among the pineapple growers. Varimax rotation attribute helps smoothen the components and reduces the level of convergence among the variables in each component (Hair et al., 2009).

The twenty-three items considered for factor analysis in this study were subjected to a reliability test to ensure internal validity. According to George and Mallery (2003), the value of 0.8 is considered as a good consistency in the instrument measurement showing that 
variables are consistent and reliable. The measure of sampling adequacy is determined by Keiser-MeyerOlkin (KMO) and its value of at least 0.6 or higher with an eigenvalue greater than 1 is considered meaningful for factor analysis (Hair et al., 2009). The Bartlett's test of sphericity tests the hypothesis that the correlation matrix is an identity matrix that is all the variables are uncorrelated. If the significance value for this test is less than 0.05 , this indicates that the test is significant, thus, factor analysis is suitable. In computing the factor analysis, the "option" tool in SPSS software was used to suppress the scores to show the results of those variables above 0.5 . This was done to allow for easy identification of the significant variables in the components. Uncorrelated and standardized factor scores were also generated through the Anderson-Rubin method for further analysis.

\section{Results and discussion}

\subsection{Socio-demographic profiles of smallholder pineapple growers}

Table 2 reports the descriptive characteristics of the 123 respondent of pineapple growers. The results showed that most of the pineapple growers were in the age of $31-40$ years old $(50.41 \%), 20.3 \%$ were between 20-30 years, while only $8.1 \%$ of the growers were in the age bracket of 51-60 years. Majority of the respondents $(52 \%)$ are males while the rest $(48 \%)$ are females. This shows that there are more male pineapple growers than female pineapple growers in the study area. More than half $(72.4 \%)$ of the respondents had secondary school education, $17.1 \%$ attained tertiary level education, while $10.6 \%$ accomplished their secondary school education. The results also indicated that majority of the pineapple growers earned less than RM500 per month or 50.41\% and only $14 \%$ of them have a monthly income above RM1,500. In terms of experience, the majority $(70.7 \%)$ of the pineapple growers had 3-5 years of farming experience, $15.5 \%$ of them had had less than 2 years' experience, while the rest $(13.8 \%)$ had over 6 years of pineapple farming experience.

Based on the respondents, it can be summarized that a majority of smallholder pineapple growers in Samarahan Sarawak were young farmers who had less than five years' experience in pineapple sectors and had undergone only secondary school education. Moreover, they were categorized as a lower income group who received income less than RM500 per month. As stated by Marie et al. (2018), the main reasons these young farmers enter the agriculture sector were to continue with the farming of their parents or relatives and to work in nature. Moreover, the finding is in line with Zondag et al. (2015) who identified that Czech farmers lack the experience with multi-generational farming and knowledge and experience in the management of plant growing and/or animal breeding. Jaji et al. (2018) additionally expressed the same result as an increase in the farmers' experience increasing pineapple quantity supplied to the market. Further results by Kassa et al. (2017) showed that high income generated by the fruit sector was an important motivational factor for households to participate in the market. This finding concurs with that of Osmani and Hossain (2015) who reported that farmers' decisions on market entry are significantly related to the amount of farm income.

Table 2. Socio-demographic profiles

\begin{tabular}{lcc}
\hline Variable (s) & Frequency & Percent \\
\hline Age & & \\
\hline $20-30$ & 25 & 20.3 \\
$31-40$ & 62 & 50.4 \\
$41-50$ & 26 & 21.1 \\
$51-60$ & 10 & 8.1 \\
\hline Gender & & \\
\hline Male & 64 & 52 \\
Female & 59 & 48 \\
Level of education & & \\
Primary school & 13 & 10.6 \\
Secondary school & 89 & 72.4 \\
Tertiary education & 21 & 17.1 \\
\hline Monthly income & & \\
\hline Less than RM500 & 62 & 50.4 \\
RM501-RM1000 & 44 & 35.8 \\
RM501-RM1000 & 9 & 7.3 \\
RM1001-RM1500 & 3 & 2.4 \\
RM1501-RM2000 & 2 & 1.6 \\
RM2001-RM2500 & 3 & 2.4 \\
\hline Farming experience & & \\
\hline Less than 2 years & 19 & 15.5 \\
3-5 years & 87 & 70.7 \\
More than 6 years & 17 & 13.8 \\
\hline
\end{tabular}

3.2 Challenges faced by smallholder pineapple growers in selecting marketing channel

Factor analysis was conducted on the items related to the factors influencing the selection of marketing channels using Varimax rotation method and Eigenvalues greater than one as a cut-off point for the number of factors extracted. The sampling adequacy and the factorability of the data were evaluated through the Kaiser-Meiyer-Olkin indicator (KMO), which is based on correlation and partial correlation varying from 0 to 1.0. Thus, to proceed with factor analysis, the overall $\mathrm{KMO}$ value should be at least 0.6 or higher (Hair et al., 2009). The value of KMO for this study was 0.804 as shown in Table 3 which is acceptable for conducting 
factor analysis. The Barlett's test of Sphericity showed that the overall correlation matrix is not an identity and it is significant at $p<0.000$ indicating the appropriateness of extracted items for factor analysis. Furthermore, the anti-image correlation matrix revealed that the measures of sampling adequacy were well above the acceptable level of 0.5 , confirming the suitability of the data for the factor analysis (Coakes and Steeds, 2003).

Table 3. Test of sampling adequacy

Kaiser-Meyer-Olkin Measure of Sampling

Adequacy

0.804

Bartlett's Test of Sphericity

Approx. Chi-Square

1664.682

Degree of Freedom

Significance

0.000

The result shows that five factors comprising 21 items out of the initial twenty-three items met KaiserMeiyer- Olkin's criterion of having eigenvalues greater than 1 and are considered significant. These five factors collectively explained $64.704 \%$ of the total variation of the factors influencing pineapple supply as shown in Table 4 together with the factor loadings, eigenvalues, percentage of variance, as well as Cronbach's alpha. Items in the five-factor solution had factor loadings ranging from 0.503 to 0.907 . These factors are (1) Lack of market information, (2) Transportation, (3) Price volatility, (4) Distance, and (5) Product perishability. These factors are described and interpreted in Table 4.

Table 4. Challenges in selecting marketing channel

\begin{tabular}{|c|c|c|c|c|c|}
\hline \multirow{2}{*}{ Items } & \multicolumn{5}{|c|}{ Factor Loading } \\
\hline & F1 & F2 & F3 & F4 & F5 \\
\hline \multicolumn{6}{|l|}{ Lack of market information } \\
\hline Lack of market information provides higher risk in direct selling of pineapple to & 0.907 & & & & \\
\hline $\begin{array}{l}\text { Lack of market information influence the farmer's judgement in selecting marketing } \\
\text { channel for pineapple }\end{array}$ & 0.894 & & & & \\
\hline Lack of market information is a major factor in selecting marketing channel for & 0.866 & & & & \\
\hline Lack of market information lead to middleman involvement & 0.863 & & & & \\
\hline Farmers get low internet access causing them getting lack of market information & 0.767 & & & & \\
\hline
\end{tabular}

Transportation

Transportation influence farmers judgement in selecting marketing channel for 0.796

Lack of transportation facilities lead to higher risk in marketing pineapple directly to customers

Transportation is a major factor in selecting marketing channel for pineapple

Perishability of product provides higher risk in direct selling of pineapple to

0.550

Price Volatility

Price volatility influence farmers judgement in selecting marketing channel for 0.835

Price volatility lead to higher risk in marketing pineapple directly to customers

0.812

Price volatility cause farmers to sell their crop to middleman

0.787

Price volatility is a major factor in selecting marketing channel for pineapple

0.759

\section{Distance}

Distance influence farmers judgement in directly marketing the pineapple

Distance is a major factor in selecting marketing channel for pineapple

Longer distance lead to higher transportation fee

Distance provides higher risk in direct selling of pineapple to customer

Distance cause farmer to sell their crop to middleman

Product perishability

Perishability of product provides higher risk in direct selling of pineapple to

Pineapple is highly perishable product

Perishability of product cause farmers to sell their crop to middleman

Eigenvalues

Percentage of Variance (\%)

Cumulative percentage of variance $(\%)$

Cronbach's alpha

\begin{tabular}{ccccc} 
& & & & 0.708 \\
& & & & 0.578 \\
& & & & 0.541 \\
\hline 7.561 & 2.572 & 1.858 & 1.758 & 1.211 \\
19.354 & 14.425 & 12.791 & 10.419 & 7.715 \\
19.354 & 33.778 & 46.570 & 56.988 & 64.704 \\
0.931 & 0.797 & 0.750 & 0.738 & 0.693 \\
\hline
\end{tabular}




\subsubsection{Factor 1: Lack of market information}

This factor explained about $19.354 \%$ of the total variance with eigenvalue of 7.561. The factor consists of five items with the factor loadings ranging from 0.767 to 0.907 (Cronbach's Alpha $=0.931$ ). This result shows that insufficient market information is the main challenges affecting the selection of marketing channel by the pineapple growers in Samarahan. Access to market information is important because it enables farmers to make more appropriate decisions on which market to sell to and when to sell their commodity. Farmers need comprehensive market information to be able to make the right decision on the amount of product to market and which price to receive (Kyaw et al., 2018). As expressed by Jari and Fraser (2009), the availability of market information enables farmers to make informed marketing decisions related to supply and demand conditions of markets, potential buyers, bargaining and negotiation, enforcing contracts, and monitoring. Moreover, access to agricultural market information is necessary for participating in agricultural markets. Mazowa et al. (2014) mentioned in the study that poor access to markets by rural farmers is attributed by poor road infrastructure, lack of transporting means, and broadly by lack of agricultural market information. Due to lack of market information such as the price of produce, quality, and quantity of produces required at the markets, rural farmers negotiate on prices of their produce based on the information provided by traders. These factors significantly reduce the bargaining power of rural farmers thus promoting uncompetitive markets. The evidence found by Soe et al. (2015) revealed that the rice farmers who do not get enough market information are more likely to sell at the farm gate and less likely to sell through other channels such as direct sales. The statement above was parallel to the finding of this study as the pineapple growers in Samarahan who gained lack of market information provides higher risk in direct selling of pineapple to their customer and comfortable to sell their produce through the help of middlemen.

\subsubsection{Factor 2: Transportation}

This factor explained about $14.425 \%$ of the total variance with eigenvalue of 2.572 . The factor consists of four items with the factor loadings ranging from 0.550 to 0.796 (Cronbach's Alpha $=0.797$ ). The lack of accessible means of transportation or possession of own transportation is another variable found to influence the decision of the channel selection. Soe et al. (2015) studied on the factors influencing marketing channel choice by paddy rice farmers in Myanmar found that the probability of farmers selling at the farm gate to the brokers or commission men increases if they have no transportation facility and the road condition is bad. Perishable goods especially agricultural products need speedy movement and shorter route of distribution. The marketing of fresh pineapple poses a serious problem due to its high perishability. According to Das et al. (2016) in their study in Bidhan Nagar market, total losses for raw pineapples and ripened fruits were $2.5 \%$ and $29.6 \%$, respectively. The major part of loss (1.4\%) occurs during transportation of raw fruits and for ripened fruits, it is $13 \%$ which occurs in wholesalers' store. Therefore, transportation is one of the key factors that influence the smallholder pineapple growers in selecting the marketing channel to market their produce to reduce the marketing losses due to spoilage during transit.

\subsubsection{Factor 3: Price volatility}

This factor explained about $12.791 \%$ of the total variance with eigenvalue of 1.858 . The factor consists of four items with the factor loadings ranging from 0.759 to 0.835 (Cronbach's Alpha $=0.750$ ). This result shows that price of the product is one of the factors affecting the selection of marketing channel by the pineapple growers in Samarahan. Price volatility is one of the most important sources of risk for fruit and vegetable producers due to its negative effect on farm income stability (Hartwich et al., 2015). A study by Felis and Garrido (2015) analyse the impact of price volatility on the market power of retailer and wholesaler in the fresh produce supply chain and find that market power is sensitive to price volatility. Increasing price volatility caused by external shocks rises the variability of their price margins. Price of the product is a sensitive factor with a great effect on both the demand and supply of any product. A study conducted by Jaji et al. (2018) discovered that an increase in the price of pineapple in the market results in an increase in the quantity of pineapple market supply by the farmers, holding other variables constant. This result is consistent with the findings by Kyaw et al. (2018) as the price of rice had a significant effect on the rice sales volume of farmers. The results indicate that higher market prices encourage farmers to produce more, which in turn increases the proportion of rice to be sold in the market by smallholder farmers. Fresh fruits and vegetables are extremely perishable and have a relatively short shelf life and need to be sold through shorter marketing channels to reduce losses to the farmers. Soe et al. (2015) expressed that the farmers have to sell immediately after harvesting to the brokers or commission men who bargain less with farmers because they need immediate cash to pay their loans for production and household expenses. Furthermore, the inaccessibility and the bad condition of the rural roads to the market is another determinant factor affecting the channel choice. Gandorfer et al. 
(2017) stated that one of the most important sources of risk in marketing fruits and vegetable in Germany is price volatility as they give a negative impact and influence the farm income stability. Thus, the findings of this study revealed that, due to small-scale pineapple production, the smallholder pineapple growers in Samarahan are frightened to take the high risk to market their product. Instead, they choose to sell their product as fast as they can to the middlemen in order to avoid price volatility.

\subsubsection{Factor 4: Distance}

This factor explains about $10.419 \%$ of the total variance with eigenvalue of 1.758 . The factor consists of five items with the factor loadings ranging from 0.503 to 0.763 (Cronbach's Alpha $=0.738$ ). This result indicates that distance is one of the factors influencing the selection of marketing channel for pineapple growers in Samarahan. Ayalew (2015) studied the factors affecting fruit supply in the market in North Wollo, Ethiopia and found that distance to market had significantly and negatively affected marketable surplus of fruit. The result shows that an increase in the distance indicates a decrease in the quantity of supplied fruit. This result was aligned with the findings of Kyaw et al. (2018) which revealed that the longer the distance to market, the less the proportion of rice will be marketed. Therefore, the larger the distance to the market, the lower the amount of products sold in the market and instead sell their products at the farm gate. According to Soe et al. (2015), the distance to selling place has caused the rice farmers to sell their grain to brokers or commission men or send to collectors or traders at the farm gate, and less likely to sell their grain in rice mills in town. Results of the study conducted by Volpe et al. (2013) indicate that transportation costs significantly increase the costs of marketing the produced items and therefore their wholesale price. The impact of fuel prices on produce price tags depends on the distance between wholesale markets and the source of the produce, the method of transportation, the importance and timing of imports, and commodity-specific factors such as perishability. Hence, the distance of the pineapple growers to the market influences the decision in selecting marketing channel due to the higher transportation costs which reduces the quantity of supply of fruits sold to the market among smallholder pineapple growers in Samarahan.

\subsubsection{Factor 5: Product perishability}

This factor explained about $7.715 \%$ of the total variance with eigenvalue of 1.211 . The factor consists of three items with the factor loadings ranging from 0.541 to 0.708 (Cronbach's Alpha $=0.693$ ). The product perishability is one of the challenges faced by pineapple growers in choosing a marketing channel. A study was done by Baruwa (2013) in Osun state, Nigeria shows that highly perishable characteristic of pineapple coupled with the lack of storage and transportation facility is one of the constrain in the marketing of the product. Additionally, Kainga (2013) indicated that spoilage of fruits, transport risk and irregular supply was the major constraint in watermelon marketing in Bayelsa State, Nigeria. This result was consistent with outcomes of Okal (2016) which showed that the perishable nature of pineapples was third-ranked among marketing constraints to pineapple trade in selected markets in Bureti, Kenya. This means that farmers and traders were not able to store the produce for a longer period and was sometimes forced to dispose of the produce at lower than purchasing prices to minimize total loss. The marketing of pineapples is a complex and risky business because of their perishable nature and bulkiness which requires well -functioning marketing system to transfer it from the point of production to the point of consumption within a specified amount of time to maintain its freshness. This constraint poses a special challenge to smallholder pineapple growers in Samarahan because they lack the resources to access and interpret market information thus depending on the middleman to manage or market their product.

\section{Conclusion}

The results of factor analysis in this study showed that lack of market information, transportation, price volatility, distance, and product perishability was identified as the challenges affecting the selection of marketing channel among the smallholder pineapple growers in Samarahan, Sarawak. Therefore, it can be concluded that all the challenges identified in this study are the significant factors to be considered for any related agencies to enhance and sustain their competitiveness in the pineapple market and to improve farmers' livelihoods. In order to sustain its competitive position in the pineapple market, fruit supply chain management must be strengthened to avoid post-harvest losses and wastage. This will require adopting an inclusive approach such as policies, programs, and strategies pertaining to the marketing of pineapple fruits that require a collective effort and commitment from the public and private sectors. As such, the related agencies in Malaysia should venture into downstream processing to add value, instead of focusing solely on marketing the whole fruit.

\section{Conflict of interest}

The authors declare no conflict of interest. 


\section{Acknowledgements}

Indicate any source of funding or other contributors to the work in a single paragraph and kept at the minimum.

\section{References}

Arinloye, D.D.A.A., Pascucci, S., Linnemann, A.R., Coulibaly, O.N., Hagelaar, G. and Onno S.W.F. (2015). Marketing channel selection by smallholder farmers. Journal of Food Products Marketing, 21(4), 337-357. https:// doi.org/10.1080/10454446.2013.856052

Assis, K., Nurul Azzah, Z. and Mohammad, A.A. (2014). Relationship between Socioeconomic Factors, Income and Productivity of Farmers: A Case Study on Pineapple Farmers. International Journal of Research in Humanities, Arts and Literature, 2(12), 67-78

Ayalew, Y. (2015). Factors affecting fruit supply in the market: The case of Habru Woerda, North Wollo, Ethiopia Regional State, Ethiopia. Journal of Marketing and Consumer Research, 7(4), 1-11.

Barrowclough, M., Boys, K.A. and Carpio, C. (2019). Benefits, challenges and trade-offs: buyer and contract characteristics valued by small farm suppliers to wholesale marketing channels. Journal of Agricultural and Resource Economics, 44(3), 605 -623 .

Baruwa, O.I. (2013). Profitability and constraints of pineapple production in Osun Stat, Nigeria. Journal of Horticultural Research, 21(2), 59-64. https:// doi.org/10.2478/johr-2013-0022

Chaudhary, V., Kumar, V., Sunil, Vaishali, Singh, K., Kumar, R. and Kumar, V. (2019). Pineapple (Ananas cosmosus) product processing: A review. Journal of Pharmacognosy and Phytochemistry, 8(3), 46424652.

Clark, J.K. and Inwood, S.M. (2016). Scaling-up regional fruit and vegetable distribution: Potential for adaptive change in the food system. Agriculture and Human Values, 33(3), 503-519. https:// doi.org/10.1007/s10460-015-9618-7

Coakes, S.J. and Steed, L.G. (2003). SPSS version 11.0 for windows. Analysis without Anguish. Australia: Wiley.

Das, B., Das, K.K. and Roy, T.N. (2016). Study on marketing system and value addition of pineapple fruit (Ananus comosus) in West Bengal. Agricultural Economics Research Review, 29(2), 279-285. https:// doi.org/10.5958/0974-0279.2016.00055.0

David, J. (2019). Big potential for pineapple farming in
Sarawak. The Borneo Post Online. Retrieved on May 2, 2020 from https:// www.theborneopost.com/2019/01/31/big-potentialfor-pineapple-farming-in-swak/.

Fafchamps, M. and Hill, R.V. (2005). Selling at the farmgate or traveling to market. American Journal of Agricultural Economics, 87(3), 717-734. https:// doi.org/10.1111/j.1467-8276.2005.00758.x

Felis, A. and Garrido, A. (2015). Market power dynamics and price volatility in markets of fresh fruits and vegetables, Working Paper 7, ULYSSES project, EU 7th Framework Programme, Project 312182 KBBE.2012.1.4-05. Retrieved from website: https://cordis.europa.eu/docs/results/312/312182/ final1-core-reportulysses_no312182_finalversion.pdf

Gandorfer, M., Porsch, A. and Bitsch, V. (2017). Producer price volatility in the German fruit and vegetable industry. European Journal of Horticultural Science, 82(3), 149-154. https:// doi.org/10.17660/eJHS.2017/82.3.5

George, D. and Mallery, P. (2003). SPSS for Windows Step by Step: A Simple Guide and Reference. Boston: Allyn and Bacon.

Hair, J.F., Black, W.C., Babin, B.J. and Anderson, R.E. (2009). Multivariate Data Analysis. Upper Saddle River, New Jersey: Prentice Hall.

Hartwich, A., Gandorfer, M. and Bitsch, V. (2015). Risk management in fruit and vegetable production in Germany. Acta Horticulturae, 1103(23), 151-157. https://doi.org/10.17660/ActaHortic.2015.1103.23

Jaji, K., Man, N. and Nawi, N.M. (2018). Factors affecting pineapple market supply in Johor, Malaysia. International Food Research Journal, 25 (1), 366-375.

Jari, B. and Fraser, G.C.G. (2009). An analysis of institutional and technical factors influencing agricultural marketing amongst smallholder farmers in the Kat River Valley, Eastern Cape Province, South Africa. African Journal of Agricultural Research, 4(11), 1129-1137.

Joy, P.P. (2010). Benefits and uses of pineapple. Retrieved on Nov 24, 2015 from file://C:/Users/ user/Downloads/Benefitsandusesofpineapple.pdf.

Kainga, P.E. (2013). Marketing margin and determinants of net return of watermelon marketing in Yenagoa Metropolis of Bayelsa State, Nigeria. Journal of Experimental Biology and Agricultural Sciences, 1 (4), 241-247.

Kassa, G., Yigezu, E. and Alemayehu, D. (2017). Determinants of smallholder market participation among banana growers in Bench Maji Zone, 
southwest Ethiopia. International Journal of Agricultural Policy and Research, 5(11), 169-177.

Kyaw, N.N., Ahn, S. and Lee, S.H. (2018). Analysis of the factors influencing market participation among smallholder rice farmers in Magway Region, Central Dry Zone of Myanmar. Sustainability, 10(4441), 115. https://doi.org/10.3390/su10124441

Makhura, T.M. (2001). Overcoming transaction costs barriers to market participation of smallholder farmers in the Northern Province of South Africa. Pretoria: Pretoria University, $\mathrm{PhD}$ Dissertation.

Marie, S.P., Ondřej, S., Tomáš, M., Daniela, S. and Miloslav, D. (2018). What are the motivation and barriers of young farmers to enter the sector? Agris on-line Papers in Economics and Informatics, 10(4), 79-87. https://doi.org/10.7160/aol.2018.100409

Mawazo, M.M., Michael, K. and Ko, J. (2014). Access to agricultural market information by rural farmers in Tanzania. International Journal of Information and Communication Technology Research, 4(7), 264273.

Ministry of Modernisation of Agriculture, Native Land and Regional Development Sarawak. (2020). Big Potential for Pineapple Farming In Sarawak. Retrieved on September 16, 2020 from MANRED Website: https://manred.sarawak.gov.my/modules/ web/pages.php?

mod=news\&sub=news_view\&nid $=194$

Nurul Hidayah M.S. and Fazleen A.F. (2019). Profitability of Pineapple Production (Ananas comosus) among Smallholders in Malaysia. International Journal of Recent Technology and Engineering, 8(4). https://doi.org/10.35940/ ijrte.D7780.118419

Okal, J.O. (2017). Constraints and opportunities of pineapple marketing in Bureti Sub County, Kericho County, Kenya. International Journal of Science and Research, 7(12), 870-875.

Osmani, A.O. and Hossain, E. (2015). Market participation decision of smallholder farmers and its determinants in Bangladesh. Economics of Agriculture, 62(1), 163-179. https://doi.org/10.5937/ ekoPolj1501163G

Sigei, G.K. (2014). Determinants of Market Participation Among Small-Scale Pineapple Farmers in Kericho County, Kenya. Kenya: Egerton University, MSc Thesis.

Soe, P.P., Moritaka, M. and Fukuda, S. (2015). An analysis of the factors influencing marketing channel choice by paddy rice farmers in Myanmar. Journal of the Faculty of Agriculture, Kyushu University, 60(2), $535-542$.
Stern, L.W., Ansary, A.I. and Coughlan, A.T. (1996). Marketing Channels. 5thed. Upper Saddle River, New Jersey: Prentice Hall.

Thalip, A.A., Tong, P.S. and Casey, N. (2015). The MD2 "super sweet" pineapple (Ananas comosus). UTAR Agriculture Science Journal, 1(4), 2-3.

United Nations Conference on Trade and Development (UNCTAD). (2016). Pineapple. Retrieved on Dec 12, 2015 from https://unctad.org/en/ PublicationsLibrary/

INFOCOMM_cp09_Pineapple_en.pdf.

Veno, J. (2018). The Goodness of Pineapples. The Borneo Post Online. Retrieved on March 18, 2020 from https:/www.theborneopost.com/2018/08/19/the -goodness-of-pineapples/

Volpe, R., Roeger, E. and Leibtag, E. (2013). How transportation costs affect fresh fruit and vegetable prices. Economic Research Report. Retrieved from USDA website: https://www.ers.usda.gov/webdocs/ publications/45165/41077_err160.pdf?v=1911

Zakaria, N.A. and Abdul Rahim, A.R. (2014). An overview of fruit supply chain in Malaysia. Jurnal Mekanikal, 37, 36-46.

Zondag, M.J., Koppert, S., de Lauwere, C., Sloot and Pauer, P.A. (2016). Needs of young farmers. Report I of the pilot project: Exchange programmes for young farmers. Luxembourg: Publications Office of the European Union. 